\title{
NGHI QUYẾT HộI NGHỊ TRUNG ƯƠNG 8 KHÓA XI VỀ ĐỔI MỚI CĂN BẢN, TOÀN DIỆN GIÁO DỤC VÀ ĐÀO TẠOO
}

Lời Tòa soạn: Ngày 04-11-2013, Tổng Bí thư Nguyễn Phú Trọng đã ký ban hành Nghị Quyết (số 29-NQ/TW) Hội nghị Trung ương 8 khóa XI về đổi mới căn bản, toàn diện giáo duc và đào tạo, đáp ứng yêu cầu công nghiệp hóa, hiện đại hóa trong điều kiện kinh tế thị trường định hướng xã hội chủ nghĩa và hội nhập quốc tế. Tạp chí Khoa học Đại học Đồng Tháp xin giới thiệu toàn văn Nghị quyết này.

\section{A- TÌNH HİNH VÀ NGUYÊN NHÂN}

1. Thực hiện Nghị quyết Trung ương 2 khóa VIII và các chủ trương của Đảng, Nhà nước về định hướng chiến lược phát triển giáo dục - đào tạo trong thời kỳ công nghiệp hóa, hiện đại hóa, lĩnh vực giáo dục và đào tạo nước ta đã đạt được những thành tựu quan trọng, góp phần to lớn vào sự nghiệp xây dựng và bảo vệ Tổ quốc.

Cụ thể là: Đã xây dựng được hệ thống giáo dục và đào tạo tương đối hoàn chỉnh từ mầm non đến đại học. Cơ sở vật chất, thiết bị giáo dục, đào tạo được cải thiện rõ rệt và từng bước hiện đại hóa. Số lượng học sinh, sinh viên tăng nhanh, nhất là ở giáo dục đại học và giáo dục nghề nghiệp. Chất lượng giáo dục và đào tạo có tiến bộ. Đội ngũ nhà giáo và cán bộ quản lý giáo dục phát triển cả về số lượng và chất lượng, với cơ cấu ngày càng hợp lý. Chi ngân sách cho giáo dục và đào tạo đạt mức $20 \%$ tổng chi ngân sách nhà nước. Xã hội hóa giáo dục được đẩy mạnh; hệ thống giáo dục và đào tạo ngoài công lập góp phần đáng kể vào phát triển giáo dục và đào tạo chung của toàn xã hội. Công tác quản lý giáo dục và đào tạo có bước chuyển biến nhất định.

Cả nước đã hoàn thành mục tiêu xoá mù chữ và phổ cập giáo dục tiểu học vào năm 2000; phổ cập giáo dục trung học cơ sở vào năm 2010; đang tiến tới phổ cập giáo dục mầm non cho trẻ 5 tuổi; củng cố và nâng cao kết quả xoá mù chữ cho người lớn. Cơ hội tiếp cận giáo dục có nhiều tiến bộ, nhất là đối với đồng bào dân tộc thiểu số và các đối tượng chính sách; cơ bản bảo đảm bình đẳng giới trong giáo dục và đào tạo.

Những thành tựu và kết quả nói trên, trước hết bắt nguồn từ truyền thống hiếu học của dân tộc; sự quan tâm, chăm lo của Đảng, Nhà nước, Mặt trận Tổ quốc và các đoàn thể nhân dân, của mỗi gia đình và toàn xã hội; sự tận tụy của đội ngũ nhà giáo và cán bộ quản lý giáo dục; sự ổn định về chính trị cùng với những thành tựu phát triển kinh tế - xã hội của đất nước.

2. Tuy nhiên, chất lượng, hiệu quả giáo dục và đào tạo còn thấp so với yêu cầu, nhất là giáo dục đại học, giáo dục nghề nghiệp. Hệ thống giáo dục và đào tạo thiếu liên thông giữa các trình độ và giữa các phương thức giáo dục, đào tạo; còn nặng lý thuyết, nhẹ thực hành. Đào tạo thiếu gắn kết với nghiên cứu khoa học, sản xuất, kinh doanh và nhu cầu của thị trường lao động; chưa chú trọng đúng mức việc giáo dục đạo đức, lối sống và kỹ năng làm việc. Phương pháp giáo dục, việc thi, kiểm tra và đánh giá kết quả còn lạc hậu, thiếu thực chất.

Quản lý giáo dục và đào tạo còn nhiều yếu kém. Đội ngũ nhà giáo và cán bộ quản lý 
giáo dục bất cập về chất lượng, số lượng và cơ cấu; một bộ phận chưa theo kịp yêu cầu đổi mới và phát triển giáo dục, thiếu tâm huyết, thậm chí vi phạm đạo đức nghề nghiệp.

Đầu tư cho giáo dục và đào tạo chưa hiệu quả. Chính sách, cơ chế tài chính cho giáo dục và đào tạo chưa phù hợp. Cơ sở vật chất kỹ thuật còn thiếu và lạc hậu, nhất là ở vùng sâu, vùng xa, vùng đặc biệt khó khăn.

3. Những hạn chế, yếu kém nói trên do các nguyên nhân chủ yếu sau:

- Việc thể chế hóa các quan điểm, chủ trương của Đảng và Nhà nước về phát triển giáo dục và đào tạo, nhất là quan điểm "giáo dục là quốc sách hàng đầu" còn chậm và lúng túng. Việc xây dựng, tổ chức thực hiện chiến lược, kế hoạch và chương trình phát triển giáo dục đào tạo chưa đáp ứng yêu cầu của xã hội.

- Mục tiêu giáo dục toàn diện chưa được hiểu và thực hiện đúng. Bệnh hình thức, hư danh, chạy theo bằng cấp... chậm được khắc phục, có mặt nghiêm trọng hơn. Tư duy bao cấp còn nặng, làm hạn chế khả năng huy động các nguồn lực xã hội đầu tư cho giáo dục, đào tạo.

- Việc phân định giữa quản lý nhà nước với hoạt động quản trị trong các cơ sở giáo dục, đào tạo chưa rõ. Công tác quản lý chất lượng, thanh tra, kiểm tra, giám sát chưa được coi trọng đúng mức. Sự phối hợp giữa các cơ quan nhà nước, tổ chức xã hội và gia đình chưa chặt chẽ. Nguồn lực quốc gia và khả năng của phần đông gia đình đầu tư cho giáo dục và đào tạo còn thấp so với yêu cầu.

\section{B. ĐỊNH HƯớNG ĐỔI MỚI CĂN BẢN, TOÀN DIỆN GIÁO DỤC VÀ ĐÀO TẠO I. QUAN ĐIỂM CHİ ĐẠO}

1. Giáo dục và đào tạo là quốc sách hàng đầu, là sự nghiệp của Đảng, Nhà nước và của toàn dân. Đầu tư cho giáo dục là đầu tư phát triển, được ưu tiên đi trước trong các chương trình, kế hoạch phát triển kinh tế - xã hội.

2. Đổi mới căn bản, toàn diện giáo dục và đào tạo là đổi mới những vấn đề lớn, cốt lôi, cấp thiết, từ quan điểm, tư tưởng chỉ đạo đến mục tiêu, nội dung, phương pháp, cơ chế, chính sách, điều kiện bảo đảm thực hiện; đổi mới từ sự lãnh đạo của Đảng, sự quản lý của Nhà nước đến hoạt động quản trị của các cơ sở giáo dục - đào tạo và việc tham gia của gia đình, cộng đồng, xã hội và bản thân người học; đổi mới ở tất cả các bậc học, ngành học.

Trong quá trình đổi mới, cần kế thừa, phát huy những thành tựu, phát triển những nhân tố mới, tiếp thu có chọn lọc những kinh nghiệm của thế giới; kiên quyết chấn chỉnh những nhận thức, việc làm lệch lạc. Đổi mới phải bảo đảm tính hệ thống, tầm nhìn dài hạn, phù hợp với từng loại đối tượng và cấp học; các giải pháp phải đồng bộ, khả thi, có trọng tâm, trọng điểm, lộ trình, bước đi phù hợp.

3. Phát triển giáo dục và đào tạo là nâng cao dân trí, đào tạo nhân lực, bồi dưỡng nhân tài. Chuyển mạnh quá trình giáo dục từ chủ yếu trang bị kiến thức sang phát triển toàn diện năng lực và phẩm chất người học. Học đi đôi với hành; lý luận gắn với thực tiễn; giáo dục nhà trường kết hợp với giáo dục gia đình và giáo dục xã hội. 
4. Phát triển giáo dục và đào tạo phải gắn với nhu cầu phát triển kinh tế - xã hội và bảo vệ Tổ quốc; với tiến bộ khoa học và công nghệ; phù hợp quy luật khách quan. Chuyển phát triển giáo dục và đào tạo từ chủ yếu theo số lượng sang chú trọng chất lượng và hiệu quả, đồng thời đáp ứng yêu cầu số lượng.

5. Đổi mới hệ thống giáo dục theo hướng mở, linh hoạt, liên thông giữa các bậc học, trình độ và giữa các phương thức giáo dục, đào tạo. Chuẩn hoá, hiện đại hoá giáo dục và đào tạo.

6. Chủ động phát huy mặt tích cực, hạn chế mặt tiêu cực của cơ chế thị trường, bảo đảm định hướng xã hội chủ nghĩa trong phát triển giáo dục và đào tạo. Phát triển hài hòa, hỗ trợ giữa giáo dục công lập và ngoài công lập, giữa các vùng, miền. Ủu tiên đầu tư phát triển giáo dục và đào tạo đối với các vùng đặc biệt khó khăn, vùng dân tộc thiểu số, biên giới, hải đảo, vùng sâu, vùng xa và các đối tượng chính sách. Thực hiện dân chủ hóa, xã hội hóa giáo dục và đào tạo.

7. Chủ động, tích cực hội nhập quốc tế để phát triển giáo dục và đào tạo, đồng thời giáo dục và đào tạo phải đáp ứng yêu cầu hội nhập quốc tế để phát triển đất nước.

\section{MỤC TIÊU}

\section{Mục tiêu tổng quát}

Tạo chuyển biến căn bản, mạnh mẽ về chất lượng, hiệu quả giáo dục, đào tạo; đáp ứng ngày càng tốt hơn công cuộc xây dựng, bảo vệ Tổ quốc và nhu cầu học tập của nhân dân. Giáo dục con người Việt Nam phát triển toàn diện và phát huy tốt nhất tiềm năng, khả năng sáng tạo của mỗi cá nhân; yêu gia đình, yêu Tổ quốc, yêu đồng bào; sống tốt và làm việc hiệu quả.

Xây dựng nền giáo dục mở, thực học, thực nghiệp, dạy tốt, học tốt, quản lý tốt; có cơ cấu và phương thức giáo dục hợp lý, gắn với xây dựng xã hội học tập; bảo đảm các điều kiện nâng cao chất lượng; chuẩn hóa, hiện đại hoá, dân chủ hóa, xã hội hóa và hội nhập quốc tế hệ thống giáo dục và đào tạo; giữ vững định hướng xã hội chủ nghĩa và bản sắc dân tộc. Phấn đấu đến năm 2030, nền giáo dục Việt Nam đạt trình độ tiên tiến trong khu vực.

\section{Mục tiêu cụ thể}

- Đối với giáo dục mầm non, giúp trẻ phát triển thể chất, tình cảm, hiểu biết, thẩm mỹ, hình thành các yếu tố đầu tiên của nhân cách, chuẩn bị tốt cho trẻ bước vào lớp 1 . Hoàn thành phổ cập giáo dục mầm non cho trẻ 5 tuổi vào năm 2015, nâng cao chất lượng phổ cập trong những năm tiếp theo và miễn học phí trước năm 2020. Từng bước chuẩn hóa hệ thống các trường mầm non. Phát triển giáo dục mầm non dưới 5 tuổi có chất lượng phù hợp với điều kiện của từng địa phương và cơ sở giáo dục.

- Đối với giáo dục phổ thông, tập trung phát triển trí tuệ, thể chất, hình thành phẩm chất, năng lực công dân, phát hiện và bồi dưỡng năng khiếu, định hướng nghề nghiệp cho học sinh. Nâng cao chất lượng giáo dục toàn diện, chú trọng giáo dục lý tưởng, truyền thống, đạo đức, lối sống, ngoại ngữ, tin học, năng lực và kỹ năng thực hành, vận dụng kiến thức vào thực tiễn. Phát triển khả năng sáng tạo, tự học, khuyến khích học tập suốt đời. Hoàn thành việc xây 
dựng chương trình giáo dục phổ thông giai đoạn sau năm 2015. Bảo đảm cho học sinh có trình độ trung học cơ sở (hết lớp 9) có tri thức phổ thông nền tảng, đáp ứng yêu cầu phân luồng mạnh sau trung học cơ sở; trung học phổ thông phải tiếp cận nghề nghiệp và chuẩn bị cho giai đoạn học sau phổ thông có chất lượng. Nâng cao chất lượng phổ cập giáo dục, thực hiện giáo dục bắt buộc 9 năm từ sau năm 2020.

Phấn đấu đến năm 2020, có $80 \%$ thanh niên trong độ tuổi đạt trình độ giáo dục trung học phổ thông và tương đương.

- Đối với giáo dục nghề nghiệp, tập trung đào tạo nhân lực có kiến thức, kỹ năng và trách nhiệm nghề nghiệp. Hình thành hệ thống giáo dục nghề nghiệp với nhiều phương thức và trình độ đào tạo kỹ năng nghề nghiệp theo hướng ứng dụng, thực hành, bảo đảm đáp ứng nhu cầu nhân lực kỹ thuật công nghệ của thị trường lao động trong nước và quốc tế.

- Đối với giáo dục đại học, tập trung đào tạo nhân lực trình độ cao, bồi dưỡng nhân tài, phát triển phẩm chất và năng lực tự học, tự làm giàu tri thức, sáng tạo của người học. Hoàn thiện mạng lưới các cơ sở giáo dục đại học, cơ cấu ngành nghề và trình độ đào tạo phù hợp với quy hoạch phát triển nhân lực quốc gia; trong đó, có một số trường và ngành đào tạo ngang tầm khu vực và quốc tế. Đa dạng hóa các cơ sở đào tạo phù hợp với nhu cầu phát triển công nghệ và các lĩnh vực, ngành nghề; yêu cầu xây dựng, bảo vệ Tổ quốc và hội nhập quốc tế.

- Đối với giáo dục thường xuyên, bảo đảm cơ hội cho mọi người, nhất là ở vùng nông thôn, vùng khó khăn, các đối tượng chính sách được học tập nâng cao kiến thức, trình độ, kỹ năng chuyên môn nghiệp vụ và chất lượng cuộc sống; tạo điều kiện thuận lợi để người lao động chuyển đổi nghề; bảo đảm xóa mù chữ bền vững. Hoàn thiện mạng lưới cơ sở giáo dục thường xuyên và các hình thức học tập, thực hành phong phú, linh hoạt, coi trọng tự học và giáo dục từ xa.

- Đối với việc dạy tiếng Việt và truyền bá văn hóa dân tộc cho người Việt Nam ở nước ngoài, có chương trình hỗ trợ tích cực việc giảng dạy tiếng Việt và truyền bá văn hóa dân tộc cho cộng đồng người Việt Nam ở nước ngoài, góp phần phát huy sức mạnh của văn hóa Việt Nam, gắn bó với quê hương, đồng thời xây dựng tình đoàn kết, hửu nghị với nhân dân các nước.

\section{NHIỆM VỤ, GIẢI PHÁP}

\section{Tăng cường sự lãnh đạo của Đảng, sự quản lý của Nhà nước đối với đổi mới giáo dục và đào tạo}

Quán triệt sâu sắc và cụ thể hóa các quan điểm, mục tiêu, nhiệm vụ, giải pháp đổi mới căn bản, toàn diện nền giáo dục và đào tạo trong hệ thống chính trị, ngành giáo dục và đào tạo và toàn xã hội, tạo sự đồng thuận cao coi giáo dục và đào tạo là quốc sách hàng đầu. Nâng cao nhận thức về vai trò quyết định chất lượng giáo dục và đào tạo của đội ngũ nhà giáo và cán bộ quản lý giáo dục; người học là chủ thể trung tâm của quá trình giáo dục; gia đình có trách nhiệm phối hợp với nhà trường và xã hội trong việc giáo dục nhân cách, lối sống cho con em mình.

Đổi mới công tác thông tin và truyền thông để thống nhất về nhận thức, tạo sự đồng thuận 
và huy động sự tham gia đánh giá, giám sát và phản biện của toàn xã hội đối với công cuộc đổi mới, phát triển giáo dục.

Coi trọng công tác phát triển Đảng, công tác chính trị, tư tưởng trong các trường học, trước hết là trong đội ngũ giáo viên. Bảo đảm các trường học có chi bộ; các trường đại học có đảng bộ. Cấp ủy trong các cơ sở giáo dục - đào tạo phải thực sự đi đầu đổi mới, gương mẫu thực hiện và chịu trách nhiệm trước Đảng, trước nhân dân về việc tổ chức thực hiện thắng lợi các mục tiêu, nhiệm vụ giáo dục, đào tạo. Lãnh đạo nhà trường phát huy dân chủ, dựa vào đội ngũ giáo viên, viên chức và học sinh, phát huy vai trò của các tổ chức đoàn thể và nhân dân địa phương để xây dựng nhà trường.

Các bộ, ngành, địa phương xây dựng quy hoạch dài hạn phát triển nguồn nhân lực, dự báo nhu cầu về số lượng, chất lượng nhân lực, cơ cấu ngành nghề, trình độ. Trên cơ sở đó, đặt hàng và phối hợp với các cơ sở giáo dục, đào tạo tổ chức thực hiện.

Phát huy sức mạnh tổng hợp của cả hệ thống chính trị, giải quyết dứt điểm các hiện tượng tiêu cực kéo dài, gây bức xúc trong lĩnh vực giáo dục và đào tạo.

\section{Tiếp tục đổi mới mạnh mẽ và đồng bộ các yếu tố cơ bản của giáo dục, đào tạo theo hướng coi trọng phát triển phẩm chất, năng lực của người học}

Trên cơ sở mục tiêu đổi mới giáo dục và đào tạo, cần xác định rõ và công khai mục tiêu, chuẩn đầu ra của từng bậc học, môn học, chương trình, ngành và chuyên ngành đào tạo. Coi đó là cam kết bảo đảm chất lượng của cả hệ thống và từng cơ sở giáo dục và đào tạo; là căn cứ giám sát, đánh giá chất lượng giáo dục, đào tạo.

Đổi mới chương trình nhằm phát triển năng lực và phẩm chất người học, hài hòa đức, trí, thể, mỹ; dạy người, dạy chữ và dạy nghề. Đổi mới nội dung giáo dục theo hướng tinh giản, hiện đại, thiết thực, phù hợp với lứa tuổi, trình độ và ngành nghề; tăng thực hành, vận dụng kiến thức vào thực tiễn. Chú trọng giáo dục nhân cách, đạo đức, lối sống, tri thức pháp luật và ý thức công dân. Tập trung vào những giá trị cơ bản của văn hóa, truyền thống và đạo lý dân tộc, tinh hoa văn hóa nhân loại, giá trị cốt lõi và nhân văn của chủ nghĩa Mác - Lênin và tư tưởng Hồ Chí Minh. Tăng cường giáo dục thể chất, kiến thức quốc phòng, an ninh và hướng nghiệp. Dạy ngoại ngữ và tin học theo hướng chuẩn hóa, thiết thực, bảo đảm năng lực sử dụng của người học. Quan tâm dạy tiếng nói và chữ viết của các dân tộc thiểu số; dạy tiếng Việt và truyền bá văn hóa dân tộc cho người Việt Nam ở nước ngoài.

Đa dạng hóa nội dung, tài liệu học tập, đáp ứng yêu cầu của các bậc học, các chương trình giáo dục, đào tạo và nhu cầu học tập suốt đời của mọi người.

Tiếp tục đổi mới mạnh mẽ phương pháp dạy và học theo hướng hiện đại; phát huy tính tích cực, chủ động, sáng tạo và vận dụng kiến thức, kỹ năng của người học; khắc phục lối truyền thụ áp đặt một chiều, ghi nhớ máy móc. Tập trung dạy cách học, cách nghĩ, khuyến khích tự học, tạo cơ sở để người học tự cập nhật và đổi mới tri thức, kỹ năng, phát triển năng lực. Chuyển từ học chủ yếu trên lớp sang tổ chức hình thức học tập đa dạng, chú ý các hoạt động xã hội, ngoại khóa, nghiên cứu khoa học. Đẩy mạnh ứng dụng công nghệ thông tin và truyền thông trong dạy và học. 
Tiếp tục đổi mới và chuẩn hóa nội dung giáo dục mầm non, chú trọng kết hợp chăm sóc, nuôi dưỡng với giáo dục phù hợp với đặc điểm tâm lý, sinh lý, yêu cầu phát triển thể lực và hình thành nhân cách.

Xây dựng và chuẩn hóa nội dung giáo dục phổ thông theo hướng hiện đại, tinh gọn, bảo đảm chất lượng, tích hợp cao ở các lớp học dưới và phân hóa dần ở các lớp học trên; giảm số môn học bắt buộc; tăng môn học, chủ đề và hoạt động giáo dục tự chọn. Biên soạn sách giáo khoa, tài liệu hỗ trợ dạy và học phù hợp với từng đối tượng học, chú ý đến học sinh dân tộc thiểu số và học sinh khuyết tật.

Nội dung giáo dục nghề nghiệp được xây dựng theo hướng tích hợp kiến thức, kỹ năng, tác phong làm việc chuyên nghiệp để hình thành năng lực nghề nghiệp cho người học.

Đổi mới mạnh mẽ nội dung giáo dục đại học và sau đại học theo hướng hiện đại, phù hợp với từng ngành, nhóm ngành đào tạo và việc phân tầng của hệ thống giáo dục đại học. Chú trọng phát triển năng lực sáng tạo, kỹ năng thực hành, đạo đức nghề nghiệp và hiểu biết xã hội, từng bước tiếp cận trình độ khoa học và công nghệ tiên tiến của thế giới.

\section{3. Đổi mới căn bản hình thức và phương pháp thi, kiểm tra và đánh giá kết quả giáo dục, đào tạo, bảo đảm trung thực, khách quan}

Việc thi, kiểm tra và đánh giá kết quả giáo dục, đào tạo cần từng bước theo các tiêu chí tiên tiến được xã hội và cộng đồng giáo dục thế giới tin cậy và công nhận. Phối hợp sử dụng kết quả đánh giá trong quá trình học với đánh giá cuối kỳ, cuối năm học; đánh giá của người dạy với tự đánh giá của người học; đánh giá của nhà trường với đánh giá của gia đình và của xã hội.

Đổi mới phương thức thi và công nhận tốt nghiệp trung học phổ thông theo hướng giảm áp lực và tốn kém cho xã hội mà vẫn bảo đảm độ tin cậy, trung thực, đánh giá đúng năng lực học sinh, làm cơ sở cho việc tuyển sinh giáo dục nghề nghiệp và giáo dục đại học.

Đổi mới phương thức đánh giá và công nhận tốt nghiệp giáo dục nghề nghiệp trên cơ sở kiến thức, năng lực thực hành, ý thức kỷ luật và đạo đức nghề nghiệp. Có cơ chế để tổ chức và cá nhân sử dụng lao động tham gia vào việc đánh giá chất lượng của cơ sở đào tạo.

Đổi mới phương thức tuyển sinh đại học, cao đẳng theo hướng kết hợp sử dụng kết quả học tập ở phổ thông và yêu cầu của ngành đào tạo. Đánh giá kết quả đào tạo đại học theo hướng chú trọng năng lực phân tích, sáng tạo, tự cập nhật, đổi mới kiến thức; đạo đức nghề nghiệp; năng lực nghiên cứu và ứng dụng khoa học và công nghệ; năng lực thực hành, năng lực tổ chức và thích nghi với môi trường làm việc. Giao quyền tự chủ tuyển sinh cho các cơ sở giáo dục đại học.

Thực hiện đánh giá chất lượng giáo dục, đào tạo ở cấp độ quốc gia, địa phương, từng cơ sở giáo dục, đào tạo và đánh giá theo chương trình của quốc tế để làm căn cứ đề xuất chính sách, giải pháp cải thiện chất lượng giáo dục, đào tạo.

Hoàn thiện hệ thống kiểm định chất lượng giáo dục. Định kỳ kiểm định chất lượng các cơ sở giáo dục, đào tạo và các chương trình đào tạo; công khai kết quả kiểm định. Chú trọng 
kiểm tra, đánh giá, kiểm soát chất lượng giáo dục và đào tạo đối với các cơ sở ngoài công lập, các cơ sở có yếu tố nước ngoài. Xây dựng phương thức kiểm tra, đánh giá phù hợp với các loại hình giáo dục cộng đồng.

Đổi mới cách tuyển dụng, sử dụng lao động đã qua đào tạo theo hướng chú trọng năng lực, chất lượng, hiệu quả công việc thực tế, không quá nặng về bằng cấp, trước hết là trong các cơ quan thuộc hệ thống chính trị. Coi sự chấp nhận của thị trường lao động đối với người học là tiêu chí quan trọng để đánh giá uy tín, chất lượng của cơ sở giáo dục đại học, nghề nghiệp và là căn cứ để định hướng phát triển các cơ sở giáo dục, đào tạo và ngành nghề đào tạo.

\section{Hoàn thiện hệ thống giáo dục quốc dân theo hướng hệ thống giáo dục mở, học tập suốt đời và xây dựng xã hội học tập}

Trước mắt, ổn định hệ thống giáo dục phổ thông như hiện nay. Đẩy mạnh phân luồng sau trung học cơ sở; định hướng nghề nghiệp ở trung học phổ thông. Tiếp tục nghiên cứu đổi mới hệ thống giáo dục phổ thông phù hợp với điều kiện cụ thể của đất nước và xu thế phát triển giáo dục của thế giới.

Quy hoạch lại mạng lưới cơ sở giáo dục nghề nghiệp, giáo dục đại học gắn với quy hoạch phát triển kinh tế - xã hội, quy hoạch phát triển nguồn nhân lực. Thống nhất tên gọi các trình độ đào tạo, chuẩn đầu ra. Đẩy mạnh giáo dục nghề nghiệp sau trung học phổ thông, liên thông giữa giáo dục nghề nghiệp và giáo dục đại học. Tiếp tục sắp xếp, điều chỉnh mạng lưới các trường đại học, cao đẳng và các viện nghiên cứu theo hướng gắn đào tạo với nghiên cứu khoa học. Thực hiện phân tầng cơ sở giáo dục đại học theo định hướng nghiên cứu và ứng dụng, thực hành. Hoàn thiện mô hình đại học quốc gia, đại học vùng; củng cố và phát triển một số cơ sở giáo dục đại học và giáo dục nghề nghiệp chất lượng cao đạt trình độ tiên tiến của khu vực và thế giới.

Khuyến khích xã hội hóa để đầu tư xây dựng và phát triển các trường chất lượng cao ở tất cả các cấp học và trình độ đào tạo. Tăng tỉ lệ trường ngoài công lập đối với giáo dục nghề nghiệp và giáo dục đại học. Hướng tới có loại hình cơ sở giáo dục do cộng đồng đầu tư.

Đa dạng hóa các phương thức đào tạo. Thực hiện đào tạo theo tín chỉ. Đẩy mạnh đào tạo, bồi dưỡng năng lực, kỹ năng nghề tại cơ sở sản xuất, kinh doanh. Có cơ chế để tổ chức, cá nhân người sử dụng lao động tham gia xây dựng, điều chỉnh, thực hiện chương trình đào tạo và đánh giá năng lực người học.

\section{5. Đổi mới căn bản công tác quản lý giáo dục, đào tạo, bảo đảm dân chủ, thống nhất; tăng quyền tự chủ và trách nhiệm xã hội của các cơ sở giáo dục, đào tạo; coi trọng quản lý chất lượng}

Xác định rõ trách nhiệm của các cơ quan quản lý nhà nước về giáo dục, đào tạo và trách nhiệm quản lý theo ngành, lãnh thổ của các bộ, ngành, địa phương. Phân định công tác quản lý nhà nước với quản trị của cơ sở giáo dục và đào tạo.

Đẩy mạnh phân cấp, nâng cao trách nhiệm, tạo động lực và tính chủ động, sáng tạo của các cơ sở giáo dục, đào tạo. 
Tăng cường hiệu lực quản lý nhà nước, nhất là về chương trình, nội dung và chất lượng giáo dục và đào tạo đối với các cơ sở giáo dục, đào tạo của nước ngoài tại Việt Nam. Phát huy vai trò của công nghệ thông tin và các thành tựu khoa học - công nghệ hiện đại trong quản lý nhà nước về giáo dục, đào tạo.

Các cơ quan quản lý giáo dục, đào tạo địa phương tham gia quyết định về quản lý nhân sự, tài chính cùng với quản lý thực hiện nhiệm vụ chuyên môn của giáo dục mầm non, giáo dục phổ thông và giáo dục nghề nghiệp.

Chuẩn hóa các điều kiện bảo đảm chất lượng và quản lý quá trình đào tạo; chú trọng quản lý chất lượng đầu ra. Xây dựng hệ thống kiểm định độc lập về chất lượng giáo dục, đào tạo.

Đổi mới cơ chế tiếp nhận và xử lý thông tin trong quản lý giáo dục, đào tạo. Thực hiện cơ chế người học tham gia đánh giá hoạt động giáo dục, đào tạo; nhà giáo tham gia đánh giá cán bộ quản lý; cơ sở giáo dục, đào tạo tham gia đánh giá cơ quan quản lý nhà nước.

Hoàn thiện cơ chế quản lý cơ sở giáo dục, đào tạo có yếu tố nước ngoài ở Việt Nam; quản lý học sinh, sinh viên Việt Nam đi học nước ngoài bằng nguồn ngân sách nhà nước và theo hiệp định nhà nước.

Giao quyền tự chủ, tự chịu trách nhiệm cho các cơ sở giáo dục, đào tạo; phát huy vai trò của hội đồng trường. Thực hiện giám sát của các chủ thể trong nhà trường và xã hội; tăng cường công tác kiểm tra, thanh tra của cơ quan quản lý các cấp; bảo đảm dân chủ, công khai, minh bạch.

\section{Phát triển đội ngũ nhà giáo và cán bộ quản lý, đáp ứng yêu cầu đổi mới giáo dục và đào tạo}

Xây dựng quy hoạch, kế hoạch đào tạo, bồi dưỡng đội ngũ nhà giáo và cán bộ quản lý giáo dục gắn với nhu cầu phát triển kinh tế - xã hội, bảo đảm an ninh, quốc phòng và hội nhập quốc tế. Thực hiện chuẩn hóa đội ngũ nhà giáo theo từng cấp học và trình độ đào tạo. Tiến tới tất cả các giáo viên tiểu học, trung học cơ sở, giáo viên, giảng viên các cơ sở giáo dục nghề nghiệp phải có trình độ từ đại học trở lên, có năng lực sư phạm. Giảng viên cao đẳng, đại học có trình độ từ thạc sĩ trở lên và phải được đào tạo, bồi dưỡng nghiệp vụ sư phạm. Cán bộ quản lý giáo dục các cấp phải qua đào tạo về nghiệp vụ quản lý.

Phát triển hệ thống trường sư phạm đáp ứng mục tiêu, yêu cầu đào tạo, bồi dưỡng đội ngũ nhà giáo và cán bộ quản lý giáo dục; ưu tiên đầu tư xây dựng một số trường sư phạm, trường sư phạm kỹ thuật trọng điểm; khắc phục tình trạng phân tán trong hệ thống các cơ sở đào tạo nhà giáo. Có cơ chế tuyển sinh và cử tuyển riêng để tuyển chọn được những người có phẩm chất, năng lực phù hợp vào ngành sư phạm.

Đổi mới mạnh mẽ mục tiêu, nội dung, phương pháp đào tạo, đào tạo lại, bồi dưỡng và đánh giá kết quả học tập, rèn luyện của nhà giáo theo yêu cầu nâng cao chất lượng, trách nhiệm, đạo đức và năng lực nghề nghiệp.

Có chế độ ưu đãi đối với nhà giáo và cán bộ quản lý giáo dục. Việc tuyển dụng, sử dụng, đãi ngộ, tôn vinh nhà giáo và cán bộ quản lý giáo dục phải trên cơ sở đánh giá năng lực, đạo 
đức nghề nghiệp và hiệu quả công tác. Có chế độ ưu đãi và quy định tuổi nghỉ hưu hợp lý đối với nhà giáo có trình độ cao; có cơ chế miễn nhiệm, bố trí công việc khác hoặc kiên quyết đưa ra khỏi ngành đối với những người không đủ phẩm chất, năng lực, không đáp ứng yêu cầu, nhiệm vụ. Lương của nhà giáo được ưu tiên xếp cao nhất trong hệ thống thang bậc lương hành chính sự nghiệp và có thêm phụ cấp tùy theo tính chất công việc, theo vùng.

Khuyến khích đội ngũ nhà giáo và cán bộ quản lý nâng cao trình độ chuyên môn nghiệp vụ. Có chính sách hỗ trợ giảng viên trẻ về chỗ ở, học tập và nghiên cứu khoa học. Bảo đảm bình đẳng giữa nhà giáo trường công lập và nhà giáo trường ngoài công lập về tôn vinh và cơ hội đào tạo, bồi dưỡng chuyên môn nghiệp vụ... Tạo điều kiện để chuyên gia quốc tế và người Việt Nam ở nước ngoài tham gia giảng dạy và nghiên cứu ở các cơ sở giáo dục, đào tạo trong nước.

Triển khai các giải pháp, mô hình liên thông, liên kết giữa các cơ sở đào tạo, nhất là các trường đại học với các tổ chức khoa học và công nghệ, đặc biệt là các viện nghiên cứu.

\section{7. Đổi mới chính sách, cơ chế tài chính, huy động sự tham gia đóng góp của toàn xã hội; nâng cao hiệu quả đầu tư để phát triển giáo dục và đào tạo}

Nhà nước giữ vai trò chủ đạo trong đầu tư phát triển giáo dục và đào tạo, ngân sách nhà nước chi cho giáo dục và đào tạo tối thiểu ở mức $20 \%$ tổng chi ngân sách; chú trọng nâng cao hiệu quả sử dụng vốn ngân sách. Từng bước bảo đảm đủ kinh phí hoạt động chuyên môn cho các cơ sở giáo dục, đào tạo công lập. Hoàn thiện chính sách học phí.

Đối với giáo dục mầm non và phổ thông, Nhà nước ưu tiên tập trung đầu tư xây dựng, phát triển các cơ sở giáo dục công lập và có cơ chế hỗ trợ để bảo đảm từng bước hoàn thành mục tiêu phổ cập theo luật định. Khuyến khích phát triển các loại hình trường ngoài công lập đáp ứng nhu cầu xã hội về giáo dục chất lượng cao ở khu vực đô thị.

Đối với giáo dục đại học và đào tạo nghề nghiệp, Nhà nước tập trung đầu tư xây dựng một số trường đại học, ngành đào tạo trọng điểm, trường đại học sư phạm. Thực hiện cơ chế đặt hàng trên cơ sở hệ thống định mức kinh tế - kỹ thuật, tiêu chuẩn chất lượng của một số loại hình dịch vụ đào tạo (không phân biệt loại hình cơ sở đào tạo), bảo đảm chi trả tương ứng với chất lượng, phù hợp với ngành nghề và trình độ đào tạo. Minh bạch hóa các hoạt động liên doanh, liên kết đào tạo, sử dụng nguồn lực công; bảo đảm sự hài hòa giữa các lợi ích với tích lũy tái đầu tứ.

Đẩy mạnh xã hội hóa, trước hết đối với giáo dục nghề nghiệp và giáo dục đại học; khuyến khích liên kết với các cơ sở đào tạo nước ngoài có uy tín. Có chính sách khuyến khích cạnh tranh lành mạnh trong giáo dục và đào tạo trên cơ sở bảo đảm quyền lợi của người học, người sử dụng lao động và cơ sở giáo dục, đào tạo. Đối với các ngành đào tạo có khả năng xã hội hóa cao, ngân sách nhà nước chỉ hỗ trợ các đối tượng chính sách, đồng bào dân tộc thiểu số và khuyến khích tài năng. Tiến tới bình đẳng về quyền được nhận hỗ trợ của Nhà nước đối với người học ở trường công lập và trường ngoài công lập. Tiếp tục hoàn thiện chính sách hỗ trợ đối với các đối tượng chính sách, đồng bào dân tộc thiểu số và cơ chế tín dụng cho học sinh, sinh viên có hoàn cảnh khó khăn được vay để học. Khuyến khích hình thành các quỹ học bổng, khuyến học, khuyến tài, giúp học sinh, sinh viên nghèo học giỏi. Tôn vinh, khen 
thưởng xứng đáng các cá nhân, tập thể có thành tích xuất sắc và đóng góp nổi bật cho sự nghiệp giáo dục và đào tạo.

Khuyến khích các doanh nghiệp, cá nhân sử dụng lao động tham gia hỗ trợ hoạt động đào tạo. Xây dựng cơ chế, chính sách tài chính phù hợp đối với các loại hình trường. Có cơ chế ưu đãi tín dụng cho các cơ sở giáo dục, đào tạo. Thực hiện định kỳ kiểm toán các cơ sở giáo dục - đào tạo.

Tiếp tục thực hiện mục tiêu kiên cố hóa trường, lớp học; có chính sách hỗ trợ để có mặt bằng xây dựng trường. Từng bước hiện đại hóa cơ sở vật chất kỹ thuật, đặc biệt là hạ tầng công nghệ thông tin. Bảo đảm đến năm 2020 số học sinh mỗi lớp không vượt quá quy định của từng cấp học.

Phân định rõ ngân sách chi cho giáo dục mầm non, giáo dục phổ thông, giáo dục nghề nghiệp và giáo dục đại học với ngân sách chi cho cơ sở đào tạo, bồi dưỡng thuộc hệ thống chính trị và các lực lượng vũ trang. Giám sát chặt chẽ, công khai, minh bạch việc sử dụng kinh phí.

\section{Nâng cao chất lượng, hiệu quả nghiên cứu và ứng dụng khoa học, công nghệ, đặc biệt là khoa học giáo dục và khoa học quản lý}

Quan tâm nghiên cứu khoa học giáo dục và khoa học quản lý, tập trung đầu tư nâng cao năng lực, chất lượng, hiệu quả hoạt động của cơ quan nghiên cứu khoa học giáo dục quốc gia. Nâng cao chất lượng đội ngũ cán bộ nghiên cứu và chuyên gia giáo dục. Triển khai chương trình nghiên cứu quốc gia về khoa học giáo dục.

Tăng cường năng lực, nâng cao chất lượng và hiệu quả nghiên cứu khoa học, chuyển giao công nghệ của các cơ sở giáo dục đại học. Gắn kết chặt chẽ giữa đào tạo và nghiên cứu, giữa các cơ sở đào tạo với các cơ sở sản xuất, kinh doanh. Ưu tiên đầu tư phát triển khoa học cơ bản, khoa học mũi nhọn, phòng thí nghiệm trọng điểm, phòng thí nghiệm chuyên ngành, trung tâm công nghệ cao, cơ sở sản xuất thử nghiệm hiện đại trong một số cơ sở giáo dục đại học. Có chính sách khuyến khích học sinh, sinh viên nghiên cứu khoa học.

Khuyến khích thành lập viện, trung tâm nghiên cứu và chuyển giao công nghệ, doanh nghiệp khoa học và công nghệ, hỗ trợ đăng ký và khai thác sáng chế, phát minh trong các cơ sở đào tạo. Hoàn thiện cơ chế đặt hàng và giao kinh phí sự nghiệp khoa học và công nghệ cho các cơ sở giáo dục đại học. Nghiên cứu sáp nhập một số tổ chức nghiên cứu khoa học và triển khai công nghệ với các trường đại học công lập.

Ưu tiên nguồn lực, tập trung đầu tư và có cơ chế đặc biệt để phát triển một số trường đại học nghiên cứu đa ngành, đa lĩnh vực sớm đạt trình độ khu vực và quốc tế, đủ năng lực hợp tác và cạnh tranh với các cơ sở đào tạo và nghiên cứu hàng đầu thế giới.

\section{Chủ động hội nhập và nâng cao hiệu quả hợp tác quốc tế trong giáo dục, đào tạo}

Chủ động hội nhập quốc tế về giáo dục, đào tạo trên cơ sở giữ vững độc lập, tự chủ, bảo đảm định hưởng xã hội chủ nghĩa, bảo tồn và phát huy các giá trị văn hóa tốt đẹp của dân tộc, tiếp thu có chọn lọc tinh hoa văn hoá và thành tựu khoa học, công nghệ của nhân loại. Hoàn 
thiện cơ chế hợp tác song phương và đa phương, thực hiện các cam kết quốc tế về giáo dục, đào tạo.

Tăng quy mô đào tạo ở nước ngoài bằng ngân sách nhà nước đối với giảng viên các ngành khoa học cơ bản và khoa học mũi nhọn, đặc thù. Khuyến khích việc học tập và nghiên cứu ở nước ngoài bằng các nguồn kinh phí ngoài ngân sách nhà nước. Mở rộng liên kết đào tạo với những cơ sở đào tạo nước ngoài có uy tín, chủ yếu trong giáo dục đại học và giáo dục nghề nghiệp; đồng thời quản lý chặt chẽ chất lượng đào tạo.

Có cơ chế khuyến khích các tổ chức quốc tế, cá nhân nước ngoài, người Việt Nam ở nước ngoài tham gia hoạt động đào tạo, nghiên cứu, ứng dụng, chuyển giao khoa học và công nghệ ở Việt Nam. Tăng cường giao lưu văn hoá và học thuật quốc tế.

Có chính sách hỗ trợ, quản lý việc học tập và rèn luyện của học sinh, sinh viên Việt Nam đang học ở nước ngoài và tại các cơ sở giáo dục, đào tạo có yếu tố nước ngoài tại Việt Nam.

\section{Tổ CHỨC THựC HIỆN}

1. Các cấp ủy, tổ chức đảng, Mặt trận Tổ quốc và các đoàn thể nhân dân tổ chức việc học tập, quán triệt tạo sự thống nhất về nhận thức và hành động thực hiện Nghị quyết này. Lãnh đạo kiện toàn bộ máy tham mưu và bộ máy quản lý giáo dục và đào tạo; thường xuyên kiểm tra việc thực hiện, đặc biệt là kiểm tra công tác chính trị, tư tưởng và việc xây dựng nền nếp, kỷ cương trong các trường học, phát hiện và giải quyết dứt điểm các biểu hiện tiêu cực trong giáo dục và đào tạo.

2. Đảng đoàn Quốc hội lãnh đạo việc sửa đổi, bổ sung, hoàn thiện, ban hành mới hệ thống pháp luật về giáo dục và đào tạo, các luật, Nghị quyết của Quốc hội, tạo cơ sở pháp lý cho việc thực hiện Nghị quyết và giám sát việc thực hiện.

3. Ban cán sự đảng Chính phủ lãnh đạo việc sửa đổi, bổ sung và ban hành mới các văn bản dưới luật; xây dựng kế hoạch hành động thực hiện Nghị quyết. Thường xuyên theo dõi, kiểm tra, đánh giá tình hình thực hiện và kịp thời điều chỉnh kế hoạch, giải pháp cụ thể phù hợp với yêu cầu thực tế, bảo đảm thực hiện có hiệu quả Nghị quyết.

Thành lập Ủy ban quốc gia Đổi mới giáo dục và đào tạo do Thủ tướng Chính phủ làm Chủ tịch Uỷ ban.

4. Ban Tuyên giáo Trung ương chủ trì, phối hợp với các ban đảng, ban cán sự đảng, đảng đoàn, đảng ủy trực thuộc Trung ương thường xuyên theo dõi, kiểm tra, đôn đốc, sơ kết, tổng kết và định kỳ báo cáo Bộ Chính trị, Ban Bí thư kết quả thực hiện Nghị quyết./.

\section{TM. BAN CHẤP HÀNH TRUNG ƯƠNG TỔNG BÍ THƯ}

$(Đ \tilde{a} k \dot{)})$

\section{Nguyễn Phú Trọng}

